\title{
Contents of Volume 11
}

Altena, J.W., see Tuinen, H.K. van

Balk, B.M., The new consumer price indices of Statistics Netherlands

CES, A minimum programme of priority statistics for countries in transition

CES, Declaration on "Statistics for Social Progress" for the Social Summit

Chandler, W., The value of household work in Canada, 1992

Finkel, Y., see Sabag, M.

Finlay, H., see Monty, A.

Garonna, P., Statistical “decentramento” in Italy: significance and implications

Garonna, P., Statistics facing the concerns of a changing society

Humbel, R., Geographical information systems for the analysis, presentation and dissemination of statistical data - the Swiss experience

Hundepool, A., STATview: new ways for the dissemination of statistical data

Jansson, K., Use of administrative registers for income statistics in Sweden

Longva, S., Social indicators and the measurement of living conditons. The conceptual basis and some recent Norwegian experience

Ludley, J., Migration to open system and relational databases: recent experience and lessons learned

Medin, K. and Wilson, B., Quality assurance and quality assessment in official statistics: the case of Sweden's panel Census of Agriculture

Monty, A. and Finlay, H., Strengths and weaknesses of administrative data sources: experiences of the Canadian Business Register 
Radermacher, W., Sustainable income: reflections on the valuation of nature in environmental-economic accounting

Ringqvist, M., Social statistics - changed perspectives

Sabag, M. and Finkel, Y., The Israeli Consumer Price Index: alternative computing methods for an "Item Price Index"

Schirinzi, G.M.F., Quality control in Italian agricultural censuses

Szilágyi, G., The European Comparison Programme 1990 - an international comparison of Gross Domestic Product

Tengblad, Å., Social accounting in Sweden - a progress report

Tuinen, H.K. van, Altena, J.W. and Imbens, H.C.M., Surveys, registers and integration in social statistics

Vanoli, A., Extension of national accounts: opportunities provided by the implementation of the 1993 SNA

Vogel, J., Social indicators and social reporting. Traditions and current options for the development of comparative social indicators for the European Union

Wilson, B., see Medin, K. 